\title{
Sarana Kohesi Dalam Kumpulan Puisi Cinta Karya Kahlil Gibran"Melancholic Gibran Karya-Karya Syahdu Penggugah Jiwa"
}

\author{
Rusdiyana Ulfa ${ }^{1}$, Syukur Ghazali ${ }^{1}$, Anang Santoso ${ }^{1}$ \\ ${ }^{1}$ Pendidikan Bahasa Indonesia-Universitas Negeri Malang
}

\begin{tabular}{l}
\hline INFO ARTIKEL \\
\hline Riwayat Artikel: \\
Diterima: 05-11-2019 \\
Disetujui: $15-05-2020$ \\
\hline
\end{tabular}

\section{Kata kunci:}

cohesion;

coherence;

poetry kahlil gibran;

kohesi;

koherensi;

puisi kahlil gibran

\begin{abstract}
This study aims to describe and explain the means of cohesion in the formation of the wholeness of discourse in a collection of love poems by Kahlil Gibran entitled "Melancholocic Gibran Works by Soul-Raising Syahdu". The approach used in this study uses a qualitative descriptive approach and this type of research uses the type of discourse analysis research. The data in this research are in the form of excerpts from poetry that can describe cohesion and coherence in a collection of love poems by Kahlil Gibran. The data source of this research is a collection of love poems by Kahlil Gibran entitled "Melancholocic Gibran Works by Soul-Saving Souls". The results of this research are grammatical cohesion tools used by a collection of love poems by Kahlil Gibran entitled "Melancholocic Gibran by Soul-Enhancing Syahdu Works" are exophoric references, anaphoric references, wordfora references, nominal substitution, elliptical clauses, additive and conjunctive coordinating conjunctions, are exophoric references, anaphoric references, wordaphoric references, nominal substitution, elliptical clauses, additive and conjunctive coordinating conjunctions, are exophoric references, anaphoric references, wordaphoric references, nominal substitution, elliptical clauses, additive and conjunctive coordinating conjunctions. resistance, attribute subordinative conjunction, and subordinative conjunction time.
\end{abstract}

ABSTRAK

\section{Alamat Korespondensi:}

\begin{abstract}
Abstrak: Penelitian ini bertujuan mendeskripsikan dan menjelaskan sarana kohesi dalam pembentukan keutuhan wacana pada kumpulan puisi cinta karya Kahlil Gibran yang berjudul "Melancholocic Gibran Karya-karya Syahdu Penggugah Jiwa". Pendekatan yang digunakan dalam penelitian ini menggunakan pendekatan deskriptif kualitatif dan jenis penelitian ini menggunakan jenis penelitian analisis wacana. Data dalam penelitan ini berupa kutipan larik puisi yang bisa menggambarkan kohesi dan koherensi dalam kumpulan puisi cinta karya Kahlil Gibran. Sumber data penelitian ini ialah kumpulan puisi cinta karya Kahlil Gibran yang berjudul "Melancholocic Gibran Karya-karya Syahdu Penggugah Jiwa". Hasil dari penelitan ini sarana kohesi gramatikal yang digunakan kumpulan puisi cinta karya Kahlil Gibran yang berjudul "Melancholocic Gibran Karya-karya Syahdu Penggugah Jiwa" adalah referensi eksofora, referensi anafora, referensi katafora, substitusi nomina, elipsis klausa, konjungsi koordinatif penambahan dan, konjungsi koordinatif perlawanan, konjungsi subordinatif atributit, dan konjungsi subordinatif waktu.
\end{abstract}

\author{
Rusdiyana Ulfa \\ Pendidikan Bahasa Indonesia \\ Universitas Negeri Malang \\ Jalan Semarang 5 Malang \\ E-mail: rusdiyana.ulfa@gmail.com
}

Aspek utama wacana pada umumnya ada dua, yakni unsur kohesi dan koherensi. Kohesi mengacu pada penggunaan unsur bahasa tertentu yang berfungsi untuk menghubungkan antarbagian dalam teks. Ada satu hubugan yang tidak dapat dipisahkan dari kehadiran kohesi, yaitu koherensi. Koherensi mengacu pada penggunaan unsur bahasa tertentu yang berfungsi menghubungkan makna. Arifin (2012) menjelaskan jika kohesi merupakan hubungan dalam teks yang ditandai oleh pengguna unsur bahasa, sedangkan koherensi adalah kepaduan hubungan maknawi antar bagian-bagian dalam wacana. Pada umumnya, pemanfaatan dan pemakaian bahasa di dalam puisi memang berbeda. Hal ini sebenarnya sudah disadari atau dirasakan oleh pembaca. Bahasa yang digunakan di dalam larik puisi pada umumnya berbeda dengan bahasa yang digunakan dalam kehidupan sehari-hari. Wacana merupakan unsur kebahasan yang relatif paling lengakap yang didukung oleh sruktur wacana, yaitu kohesi gramatikal dan leksikal (Alfaris (2015). Bahasa yang digunakan di setiap larik puisi memiliki ciri khas tersendiri. Sayuti (2002) menjelaskan bahwa ada penyimpangan-penyimpangan kaidah sintaskis dan semantik. Penyimpangan tersebut dilakukan untuk 
mendapatkan keestetisan didalam larik puisi. Bahasa pada puisi umumnya difungsikan untuk menyampaikan atau menggambarkan keadaan penulis yang dituangkan dalam bentuk tulisan berupa puisi. Bahasa pada konteks sastra khususnya puisi mempunyai bahasa yang khas, spesial yang diamanfaatkan oleh penyair, pamakaian dianggap tidak sesuai dengan pemakaian bahasa sehari-hari Teeuw (2015). Berdasarkan pernyataan tersebut peneliti tertarik untuk mengetahui apakah penyair juga memperhatikan kohesi dan koherensi dalam penulis puisi sedangkan dalam ranah bahasa, puisi itu mempunyai bahasa yang khas seperti yang dikemukakan oleh Teeuw.

Ardila (2018) menjelaskan bahwa bahasa dan sastra tidak dapat dipisahkan karena bahasa digunakan pengarang sebagai medium untuk menyampaikan kepada pembaca bahwa ada peristiwa yang yang ingin disampaikan melalui sebauah karya yang disebut karya sastra dalam hal ini sebuah puisi, melalui kata-kata yang terkandang mudah dipahami oleh pembaca begitupun sebaliknya. Kata-kata yang digunakan dalam puisi bukan sebuah kalimat, melainkan sebuah kesatuan larik. Kaidah sintaksis dalam puisi sering diabaikan, namun perlu diketahui untuk menafsirkan makna sebuah larik puisi terlebih dahulu menafsirkan larik tersebut dalam kesatuan sintaksis. Kesatuan sintaksis itu dapat diukur dari wawasan pembaca. Wacana dibangun dalam kesatuan sintaksis. Waluyo (1987) menjelaskan bahwa pusi juga mempunyai pola sintaksis dan semantik , sehingga puisi dapat dikatakan sebagai wacana apabila kedua pola itu saling berkaitan sehingga larik puisi tersebut menjadi wacana yang padu.

Wacana dikatakan padu apabila terdapat hubungan kohesi dan koherensi antar kalimat antar larik dalam puisi. Kohesi merujuk pada kepaduan, artinya larik yang ada didalam puisi haruslah berhubungan secara padu. Kohesi terbagi menjadi dua, yakni kohesi gramatikal dan kohesi leksikal. Analisis wacana dari segi kohesi gramatikal atau dari segi bentuk lahirnya wacana itu sendiri. Mulyana (2005) membagi empat jenis bentuk analisis wacana dari segi aspek gramatikal, yaitu referensi, subtitusi, elipsis, dan konjungsi. Kohesi leksikal dibagi menjadi lima, meliputi repetisi, sinonim, antonim, hiponim, kolokasi, sedangkan koherensi berkaitan dengan hubungan makna secara keseluruhan baik hubungan sarana-hasil, sebab-akibat, dan lain-lain.

Kohesi dan koherensi sangat penting di dalam puisi karena koherensi bukanlah bentuk formal sararana-sarana kohesi, melainkan yang paling penting adalah relasi semantik yang mendasarinya. Halliday \& Hasan (1976) menyatakan bahwa sintaksis pada dasarnya bukan sruktur wacana, melainkan struktur semantik, struktur semantik yang dimaksud adalah sebuah kalimat akan menjadi sebuah wacana apabila kalimat tersebut mempunyai hubungan makna (arti) yang saling berkaitan antara kalimat yang satu dengan kalimat yang lainya, begitupun dengan puisi apabila larik puisi ingin dikatakan sebuah wacana maka setiap larik yang ada didalam puisi harus mempunyai hubungan makna antar larik yang satu denga larik yang lainya didalam bait puisi. Sebagaimana yang dikemukakan oleh Muhyidin (2018) bahwa karya sastra adalah sebuah gambaran kehidupan yang dituangkan dalam karya fiksi yang berupa puisi yang merupakan gambaran kehidupan penulis yang dituangkan ke dalam sebuah tulisan yang diciptakan untuk memperdalam, dan menjernihkan penghayatan terhadap sisi kehidupan nyata. Berdasarkan pernyataan tersebut peneliti ingin mengetahui seberapa penting kohesi gramatikal yang digunakan dalam karya sastra untuk menjadikan puisi tersebut menjadi sebuah wacana yang padu.

Sugiarti (2002) menjelaskan bahwa karya sastra baik lisan ataupun tulis komunikasi yang ingin disampaikan untuk menyampaikan keindahan-keindahan dan peristiwa yang mampu mengajak pembaca untuk menemukan nilai-nilai kehidupan, maka pembaca harus mampu memahami secara sempurna, memiliki bekal pengetahauan dan pengalaman yang cukup dan terus menerus memahami karya sastra terutama karya sastra puisi. Kedua pernyataan diatas diperjelas oleh Widayati (2017) yang menyatakan bahwa isi wacana prosa, dapat juga berisi rekaman kehidupan manusia sehari-hari. Adapun bahasanya untuk teks sastra yang imajinatif, yaitu bersifat konotatif. Namun, sifat konotatif dalam prosa berkaitan dengan makna kias dan makna lambang (majas) diungkapkan dengan cara lisan atau tulis.

Karya sastra puisi menarik untuk dikaji dan merupakan sebuah tantangan karena komunikasi yang ada di dalamnya bersifat multitafsir dan abstrak. Abstrak dalam hal ini artinya yang ingin disampaikan penulis belum tentu sama dengan yang dipahami oleh pembaca setelah membacanya. Apalagi jika puisi tersebut merupakan puisi adaptasi atau terjemahan. Zulaiha (2014) memahami karya sastra puisi tidaklah cukup hanya dengan memahami makna kata-katanya saja, tetapi juga harus dibekali dengan pengetahuan-pengetahuan pendukung seperti sosial, budaya, dan pemahaman terhadap masyarakat pemakai bahasa itu sendiri. Oleh karena itu, seseoarang dengan wawasan yang luas, mampu menginterpretasiakan puisi dan menjadikanya sebagai objek peneltian. Hal tersebut ssesuai dengan pendapat Teeuw (2015) yang menyatakan bahwa penelitian puisi relatif dan insidental sehingga perlu dilakukan penelitian tentang puisi yang berkesinambungan terus menerus.

Peneliti tertarik untuk meneliti kohesi yang terdapat pada kumpulan puisi cinta yang berjudul "Melancholocic Gibran Karya-karya Syahdu Penggugah Jiwa" karena Kahli Gibran sebagai seoarang penyair-filosofif, gaya bahasa yang digunakan adalah gaya bahasa parabel dan aforisma yang membuat orang lebih memahami meskipun tema kajian yang diangkatnya adalah dimensi esoteris dan mistis Fais (2005). Puisi-puisinya dan karya roman semi puitisnya begitu dalam dan kaya warna. Rangkaian kata-kata yang begitu romantis dan mudah dicerna namun, tak jarang juga menggunakan ungkapan-ungkapan yang dalam dan penuh filosofi, gaya tutur Kahlil Gibran yang sering memamaki bahasa parabel dan aforisma, tema yang diangka adalah dimensi esoteris dan mestis Faiz. Berdasarkan paparan konteks penelitian maka peneliti ingin meneliti tentang kohesi dan koherensi dalam pembentukan keutuhan wacana kumpulan puisi cinta karya Kahlil Gibran. 
Penelitian tentang kohesi dan koherensi bukan penelitian pertama, penelitian sejenis pernah diteliti oleh beberapa peneliti. Pertama, penelitiaan yang diteliti oleh Sumarlam (2003) dengan judul penelitian Analisis Wacana Puisi Jawa "Jaka Ijo \& Tresna Wulan" Karya N. Sakadani Tinjawan dari Segi Konteks Kulturar dan situasi serta Aspek Gramatikal dan Leksikal. Dari hasil penelitian ini diperoleh hasil penelitian aspek-aspek gramatikal yang dimanfaatkan oleh penyair sebagai peranti pendukung kepaduan wacana puisi Jaka Ijo \& Tresnawulan, meliputi (1) referensi, (2) substitusi, (3) ellipsis, dan (4) konjungsi. Kedua (Zulaiha, 2014) dengan judul penelitian Analisis Kohesi Gramatikal dan Leksikal dalam Novel Jemini Karya Suparto Brata. Dari hasil penelitain ini diperoleh bahwa terdapat kohesi gramatikal dan kohesi leksikal pada novel Jemini karya Suparto Brata. Kohesi gramatikal dan kohesi leksikal antarkalimat pada novel Jemini. Kohesi gramatikal antarkalimat pada novel Jemini karya Suparto Brata, meliputi (a) pengacuan (referensi), (b) penyulihan (substitusi), (c) pelesapan (ellipsis), kata penghubung (konjungsi), kohesi leksikal pada novel Jemini karya Suparto Brata, meliputi (a) repetisi, (b) sinonim, (c) antonim (d) hiponim, dan (e) ekuivalensi. Ketiga penelitian Yuniati \& Chairunnisa (2018) dengan judul penelitian Kohesi pada Novel "Cinta Suci Zahrana" Karya Habiburahman El Shirazy. Dari hasil penelitian diperoleh bahwa terdapat kohesi gramatikal yang meliputi pengacuan, penggantian, pelesapan, dan perangkaian. Kohesi leksikal yang terdapat pana penelitian ini adalah repetisi atau pengulangan, antonim, kolokasi, hiponimi, dan ekuivalensi. Keempat penelitian Herianah (2014) dengan judul penelitian Kohesi Gramatikal dan Leksikal dalam Wacana Puisi "Tadarusku Untukmu” Karya Sus S. Hardjono. Dari hasil penelitian ini diperoleh semua jenis kohesi, baik kohesi gramatikal dan kohesi leksikal yang terdapat pada bait puisi tersebut.

Perbedaan penelitian ini dengan penelitian yang disebutkan di atas, dilihat dari objek penelitian, penelitan sebelumnya didominasi penggunaan karya sastra berupa cerpen dan novel, hanya ada satu penelitian yang menggunakan karya sastra puisi satu peneli sedangkan objek penelitian ini menggunakan kumpulan puisi cinta karya Kahlil Gibran, karya sastra puisi penelitian sebelumnya menggunakan karya sastra puisi berbahasa Jawa, sedangkan penelitian ini menggunakan karya sastra puisi bahasa terjemahan dari bahasa Inggris ke dalam bahasa Indonesia. Penelitian ini meneliti tentang sarana koherensi dalam pembentukan ketuhan wacana dalam kumpulan puisi cinta karya Kahlil Gibran, sedangkan penelitian sebelumnya meneliti tentang penggunaan kohesi gramatikal dan kohesi leksikal. Persamaan penelitian ini dengan penelitian sebelumya yaitu, terletak pada acuannya, yaitu untuk mengetahui keutuhan wacana yang ada di dalam tulisan karya sastra berupa novel, cerpen dan kumpulan puisi cinta karya Kahlil Gibran. Penelitian ini mempunyai kesamaan dengan penelitian yang dilakukan oleh Sari (2017) yang meneliti kohesi leksikal dan gramatikal yang digunakan dalam narasi "Batu Lelah" untuk mengetahui jenis-jenis kohesi gramatikal dan kohesi leksikal yang digunakan dalam narasi tersebut.

Keterbatasan dalam penelitian ini berkaitan dengan objek penelitian yang diambil dari puisi terjemahan oleh Dian Vita Elyanti, yaitu kumpulan puisi cinta karya Kahlil Gibran yang berjudul "Melancholic Gibran Karya-karya Syahdu Penggungah Jiwa" tersebut merupakan puisi dengan bahasa asli bahasa Inggris. Jadi, pengambilan puisi sebagai sumber penelitian difokuskan sesuai dengan terjemahan dari penerjemah.

\section{METODE}

Pendekatan yang digunakan dalam penelitian ini menggunakan pendekatan deskriptif kualitatif dan jenis penelitian ini menggunakan jenis penelitian analisis wacana. Sudaryanto (1988) menyatakan bahwa pendekatan deskriptif adalah pendekatan yang lebih menandai pada hasil penelitian yang bersangkutan dengan bahasa dengan cara menandai cara penggunaan bahasa tahap demitahap, langkah demi langkah. Deskriptif masalah terhadap objek penelitian yang dipilih didasarkan pada fakta-fakta apa adanya. Pendekatan ini digunakan dengan maksud untuk memecahkan masalah yang sedang dihadapi oleh peneliti, yaitu tentang sarana kohesi gramatikal dalam pembentukan keutuhan wacana pada kumpulan puisi cinta karya Kahlil Gibran.

Pendekatan deskriptif kualitataif dalam penelitian ini juga digunakan untuk memberikan gambaran secara alamiah tentang penggunaan satuan-satuan lingual larik-larik yang terkait secara sruktural yang terwujud dalam kumpulan puisi karya Khalil Gibran. Jenis penelitian ini menggunakan jenis penelitian analisis wacana, Baryadi (2002) mengatakan bahwa analisis wacana adalah kegiatan mengkaji wacana, baik dari segi internal maupun eksternal. Dalam penelitan ini puisi yang dikaji dari aspek keutuhan sruktur wacana, yaitu kohesi gramatikal. Data dalam penelitan ini berupa kutipan larik puisi yang daapt menggambarkan kohesi dan koherensi dalam kumpulan puisi cinta karya Kahlil Gibran yang berjudul "Melancholocic Gibran Karya-karya Syahdu Penggugah Jiwa. Data tersebut kemudian ditafsirkan dalam bentuk kohesi. Kohesi gramatikal, meliputi referensi, subtitusi, elipsis, dan konjungsi.

\section{HASIL}

Hasil dari penelitan ini. sarana kohesi gramatikal yang digunakan kumpulan puisi cinta karya Kahlil Gibran yang berjudul "Melancholocic Gibran Karya-karya Syahdu Penggugah Jiwa" adalah referensi eksofora, referensi anafora, referensi katafora, substitusi nomina, elipsis nomina dan elipsis klausa, konjungsi koordinatif penambahan dan, konjungsi koordinatif perlawanan, konjungsi subordinatif atributit, dan konjungsi subordinat waktu. 


\section{PEMBAHASAN}

Terdapat dua unsur penting dalam analisis wacana, yaitu kohesi dan koherensi. Anjani (2013) menjalakan kohesi merupakan kepaduan bentuk yang secara struktural membentuk ikatan sintaktikal dan berkenaan dengan hubungan bentuk antara bagian-bagian dalam suatu wacana. Wacana memliki sruktur yang disebut unsur kohesi gramatikal, salah satu unsur gramatikal tersebut adalah referensi Bunga (2017). Mandowen (2016) menjelaskan referensi adalah kohesi gramatikal yang berupa unsur bahasa tertentu mengacu unsur bahasa yang mendahuluinya atau mengikutinya. Wiana (2011) membagi tiga kemungkinan arah rujukan, yaitu (1) anafora, (2) katafora, dan (3) endofora. Referensi anafora mengacu ke partisipan di belakang atau ke partisipan yang telah disebutkan kemudian, katafora mengacu ke depan atau ke partisipan yang telah disebutkan atau ditampilkan sebelumnya, sedangkan eksofora tidak merujuk ke belakang atau ke partisipan yang telah disebutkan dan ke depan atau ke partisipan yang akan dikatakan, tetapi keluar dari yang dicupkan atau dituliskan. Ada tiga jenis referensi yang digunakan pada kumpulan puisi cinta karya Kahlil Gibran yang berjudul "Melancholic Gibran Karyakarya Syahdu Penggugah Jiwa “, yang selanjutnya disingkat menjadi “MGKSPJ” yaitu referensi eksofora, referensi anafora, dan referensi katafora yang akan dijelaskan sebagai berikut.

\section{Referensi Eksofora}

Ada empat jenis pronomina yang digunakan sebagai referensi atau acuan eksofora, yaitu pronomina atau kata ganti persona pertama tunggal, pronomina atau kata ganti ketiga jamak, pronomina atau kata ganti ketiga tunggal, dan pronomia pertama jamak. Eksofora yang digunakan pada kumpulan puisi cinta karya Kahlil Gibran yang berjudul "MGKSPJ".

Referensi eksofora yang digunakan pada kumpulan puisi cinta karya Kahlil Gibran yang berjudul "MGKSPJ" digunakan sebagai acuan yang mengacu pada penulis dari puisi, yaitu Kahlil Gibran yang bisa berperan sebagai pelaku cinta, dan juga bisa berperan sebagai korban cinta dalam setiap bait atau larik puisi. Pronomina atau kata ganti pertama tunggal aku dan $k u$ mengacu kepada pelaku cinta, pronomina atau kata ganti ketiga jamak kami, pronomina ketiga tunggal dia mengacu pada pelaku cinta, pronomina atau kata ganti ketiga tunggal dia juga mengacu pada pelaku cinta, dan pronomia pertama jamak kita mengacu pada korban cinta.

Pronomina atau kata kata ganti yang digunakan sebagai referensi atau acuan eksofora yang mengacu pada sesuatu yang berada di luar bait atau larik puisi, yaitu pelaku cinta dan korban cinta. Referensi eksoforis tidak menentukan kohesi suatu larik atau bait puisi secara langsung karena tidak mengaitkan secara langsung bagian-bagian dari larik atau bait puisi tersebut. Bait atau larik yang menggunakan jeni kohesi gramatikal referensi eksofora digunakan untuk menjelaskan kepada pembaca bahwa penulis puisi (Kahlil Gibran) tidak selamanya menjadi korban cinta, tetapi dia juga dapat menjadi pelaku cinta. Referensi eksofora terdapat pada bait ketiga puisi yang berjudul "Gita Cinta", bait kesatu dan bait ketigabelas puisi yang berjudul "Panggilan Pecinta", dan bait kesatu puisi yang berjudul "Bekerja dengan Cinta"

\section{Referensi Anafora}

Referensi anafora yang digunakan pada kumpulan puisi cinta yang karya Kahlil Gibran yang berjudul "MGKSPJ" mengacu pada korban cinta dan sesuatu yang berkaitan dengan alat cinta. pronomina atau kata ganti pertama tunggal aku mengacu pada mawar sebagai alat cinta, pronomina atau kata ganti ketiga tunggal dia, dan pronomina atau kata nya mengacu pada bibir si cantik sebagai alat cinta. Pronomina atau kata ganti kedua tunggal engkau, mu, dan kau yang mengacu pada kekasih. Referensi anafora yang terdapat pada kumpulan puisi cinta karya karya Kahlil Gibran yang berjudul "Melancholic Gibran Karya-karya Syahdu Penggugah Jiwa “ ada tiga jenis pronomina atau kata ganti yang digunakan dalam satu bait puisi, yaitu pronomina engkau, mu, dan engkau yang mengacu pada kekasih.

Pronomina persona atau kata ganti yang diklitikan pada kumpulan puisi cinta karya Kahlil Gibran yang berjudul "MGKSPJ" yang mengacu secara anafora adalah pronomina atau kata ganti persona kedua jamak mu yang diklitikan dengan kata kamar, diri, dan hati, dalam relasi posesif ada yang mengacu pada kekasih dan ada yang mengacu kepada seorang petani, kata yang diklitikan tersebut ada yaang bersifat insani ada yang bersifat non insani. Pronomina persona dalam yang digunakan dalam kata ini yang bersifat relasi tak terangsingkan karena pronomina atau kata ganti kedua jamak mu selalu melekat pada unsur keseluruhan. Referensi anafora terdapat bait kedua puisi yang berjudul "Gita Cinta, bait kedua puisi yang berjudul "Panggilan Pecinta, dan bait kedelapan puisi yang berjudul "Bekerja dengan Cinta".

\section{Referensi Katafora}

Wiyanti \& Dini (2017) menjelaskan bahwa referensi katafora termasuk referensi endoforik. Referensi katafora adalah pengacuan pronomina terhadap anteseden yang terletak di kanan. Referensi katafora yang digunakan pada kumpulan puisi cinta karya Kahlil Gibran yang berjudul “MGKSPJ” mengacu pada sesuatu yang berperan sebagai korban cinta yang ada pada larik atau bait kumpulan puisi cinta ini. Pronomina atau kata ganti yang digunakan sebagai referensi katafora adalah pronomina atau kata ganti ketiga tunggal dia dan nya. Pronomina atau kata ganti yang digunakan sebagai referensi katafora adalah pronomina atau kata ganti ketiga tunggal dia dan nya tidak hanya mengacu pada korban cinta, tetapi juga mengacu kepada sesuatu di luar manusia (noninsani), yaitu salah satu acuannya akar dan pohon. 
Kumpulan puisi cinta karya Kahlil Gibran yang berjudul "MGKSPJ” pada setiap larik atau baitnya tidak hanya menggunakan satu jenis pronomomina atau kata ganti melainkan dua atau lebih pronomina atau kata yang digunakan. Pronomina atau kata ganti yang digunakan pada satu bait atau larik puisi terkadang memiliki referensi atau acuan yang sama, dan bisa juga memiliki referensi atau atau yang berbeda, ada yang mengacu secara eksofora, anafora, kafafora, dan bisa juga mengacu secara endofora.

Samahalnya dengan referensi anafora, dalam referensi katafora juga menggunakan pronomina persona dalam relasi posesif yang ditandai dengan penggunaan pronomina atau kata ganti nya diklitikan pada kumpulan puisi cinta karya Kahlil Gibran yang berjudul "MGKSPJ" yang mengacu secara katafora adalah pronomina atau kata ganti nya yang diklitikkan denga kata bagian dan satu-satu. kata yang diklitikan tersebut ada yaang bersifat insani ada yang bersifat non insani. Pronomina persona dalam yang digunakan dalam kata ini yang bersifat relasi tak terangsingkan karena pronomina atau kata ganti nya selalu melekat pada unsur keseluruhan.

Ketiga jenis referensi yang digunakan pada kumpulan puisi cinta karya Kahlil Gibran yang berjudul "MGKSPJ", yaitu referensi eksofora, referensi anafora, dan referensi katafora yang mengacu pada pelaku cinta, korban cinta dan alat cinta berfungsi memberikan interpretasi kepada pembaca bahwa Kahli Gibran tidak selamanya menjadi korban cinta, tetapi sebaliknya dia juga bisa menjadi pelaku cinta. Referensi katafora terdapat pada bait kedua puisi yang berjudul "Gita Cinta", bait keempat puisi yang berjudul "Cinta", dan bait kelima puisi yang berjudul " Tentang Cinta".

Yolanda, Zahar, \& Sujoko (2018) menjelaskan bahwa substitusi adalah proses penggantian sebuah unsur bahasa yang menghasilkan variasi penggunaan sebuah unsur bahasa. Substitusi yang digunakan pada kumpulan puisi cinta karya Kahlil Gibran yang berjudul "MGKSPJ" hanya menggunakan satu jenis substitusi, yaitu substitusi nomina. Substitusi yang digunakan pada kumpulan bait puisi ini adalah kata ganti nomina atau benda yang berbentuk orang. Rani, dkk. (2004) mengatakan bahwa kata ganti orang meruapakan kata yang menggantikan nama orang atau beberapa orang. Penggunaan kohesi gramatikal substitusi nomina yang digunakan pada kumpulan puisi cinta karya Kahlil Gibran yang berjudul "MGKSPJ" akan dibahas sebagai berikut.

\section{Substitusi Nomina}

Jenis kohesi gramatikal substitusi nomina dapat diketahui bahwa pronomina atau kata ganti yang digunakan pada kumpulan puisi cinta karya Kahlil Gibran yang berjudul "MGKSPJ" menggantikan nomina manusia atau penulis dari puisi ini yang bisa berperan sebagai pelaku cinta dan korban cinta, pada puisi kumpulan puisi cinta karya Kahlil Gibran yang berjudul "MGKSPJ" tidak hanya menggunakan satu pronomina atau kata ganti melainkan lebih dari satu pronomina atau kata ganti yang digunakan yang menggantikan atau digantikan oleh unsur yang sama dan menggantikan atau digantikan unsur yang berbeda pula di dalam bait puisi.

Penjelasan di atas sesuai dengan pendapat Halliday \& Hasan (1976) yang menyatakan bahwa substitusi adalah penggantian suatu unsur wacana dengan unsur lain yang acuannya tetap sama dengan unsur yang lebih besar, tetapi pada bait kumpulan puisi cinta karya Kahlil Gibran yang berjudul "MGKSPJ" unsur yang tergantikan maupun unsur yang digantikan berupa nomina atau kata benda dan prononima atau kata ganti. Substitusi nomina yang digunakan pada kumpulan puisi cinta karya Kahlil Gibran yang berjudul "MGKSPJ" berfungsi untuk menghadirkan varisi bentuk penggunaan unsur bahasa, dan pemperoleh unsur pembeda, meskipun hanya menggantikan nomina manusia (penulis puisi) yang dapat berperan sebagai pelaku cinta dan korban cinta. Substitusi nomina terdapat pada bait ketujuh dan bait ketujuh puisi yang berjudul " Tentang Cinta" bait ketujuh puisi yang berjudul "Panggilan Pecinta", dan bait kesembilanbelas puisi yang berjudul "Bekerja dengan Cinta".

Inilah yang membedakan substitusi yang digunakan pada kumpulan puisi cinta karya Kahlil Gibran yang berjudul "MGKSPJ" dengan substitusi yang digunakan pada tulisan lainnya yang bisa saja menggunakan jenis substitusi verba, substitusi klausa, dan substitusi metafora, sedangkan pada kumpulan bait puisi cinta ini hanya menggunakan satu jenis subtitusi saja, yaitu substitusi nomina. Referensi dan substitusi mempunyai kemiripan hanya yang membedakan referensi merupakan hubungan makna sedangkan substitusi merupakan hubungan leksikal atau gramatikal. Selain itu, substitusi dapat berupa proverba, yaitu kata-kata yang digunakan untuk menunjukan tindakan, keadaan, hal, atau isi bagian wacana yang sudah disebutkan sebelum atau sesudahnya juga dapat berupa substitusi klausal Mandia (2015).

\section{Kohesi Gramatikal Elipsis}

Ijar, Afria, \& Sanjaya (2019) menjelaskan elipsis adalah salah satu jenis kohesi gramatikal yang berpa penghilngan unsur bahasa tertentu yang telah disebutkan sebelumnya yang bisa berupa kata, frase, dan klausa. Ada dua jenis kohesi gramatikal elipsis yang digunakan pada kumpulan puisi cinta karya Kahlil Gibran yang berjudul "MGKSPJ", yaitu elipsis nomina dan elipsis klausa. 


\section{Elipsis Nomina}

Elipsis nomina adalah pelepasan nomina baik maupun frasal. pada kumpulan puisi cinta karya Kahlil Gibran yang berjudul "MGKSPJ" bait atau larik yang menggunakan jenis kohesi gramatikal elipsis nomina sebenarnya sudah diketahui oleh pembaca berdasarkan konteks dari larik atau bait puisi tersebut. elipsis atau pelepasan untuk efesiensi penggunaan unsur bahasa dan kepraktisan penggunaan unsur bahasa guna untuk mendukung bait atau larik pada kumpulan puisi ini menjadi wacana yang padu.

\section{Elipsis Klausa}

Elipsis atau pelepasan klausa yang terdapat pada kumpulan puisi cinta karya Kahlil Gibran yang berjudul "MGKSPJ" berkedudukan sebagai subjek atau pelaku pekerjaan. Subjek tersebut sebenarnya dapat dicari pada bait sebelumnya. Kohesi gramatikal elipsis nomina yang diguakan pada kumpulan puisi cinta karya Kahlil Gibran yang berjudul "MGKSPJ" hanya sebagian, jika dilepaskan keseluruhan maka pembaca akan kesulitan untuk mencari karena ini merupakan karya sastra yang sangat berbeda dengan tulisan-tulisan lainnya, yang bisa lebih muda dicari unsur yang dilepaskan oleh pembaca.

Mengenai kohesi gramatikal substitusi dan tidak akan terlepas dari yang namanya konteks. Wiyanti (2016) membagi dua jenis konteks dalam karya sastra, yaitu (1) konteks bahasa disebut "koteks", (2) konteks di luar bahasa disebut "konteks situasi" dan "konteks budaya". Dalam wacana konteks situasi dapat dipahami atau dilakukan dengan beberapa penafsiran, yaitu penafsiran personal. Penafsiran lokasional, penafsiran temporal, dan penafsiran analogi. Penelitan ini untuk menentukan jenis kohesi gramatikal substitsi dan elipsis mengggunakan penafsiran personal dengan konteks memahami kebudayaan dari penulis puisi (Kahlil Gibran).

\section{Kohesi Gramatikal Konjungsi}

Indrawati (2015) Menjelaskan bahwa konjungsi merupakan bentuk atau satuan kebahasan yang berfungsi sebagai penghububung, perangkai antara kata dengan kata, frase dengan frase, kluasa dan kluasa, kalimat dengan kalimat, dan seterusnya. Penggunaan konjungsi sebagai piranti kohesi dalam bahasa Indonesia menunjukkan pola tertentu. Konjungsi digunakan dengan mempertimbangkan logika berpikir. Penggunaan konjungsi yang tidak mempertimbangkan logika akan membuat wacana menjadi tidak apik. Logika berpikir itu bergantung pada piranti kohesi yang digunakan atau sebaliknya Aflahah (2012) pendapat ini sesuai dengan konjungsi yang digunakan pada kumpulan puisi cinta karya Kahlil Gibran yang berjudul "MGKSPJ" karena dalam menggunakan kohesi gramatikal konjungsi mempertingkan logika untuk menjadikan larik atau bait puisi tersebut menjadi sebuah wacana yang padu. Jenis kohesi gramatikal yang digunakan pada kumpulan puisi pada kumpulan puisi cinta karya Kahlil Gibran yang berjudul "MGKSPJ" ada tiga jenis kohesi gramatikal konjungsi, yaitu konjungsi koordianatif penambahan dan, konjungsi koordinatif perlawanan, konjungsi subordinatif atribut, dan konjungsi subordinatif waktu yang akan dibahas berikut.

\section{Konjungsi Koordinatif Penambahan dan}

Konjungsi koordinatif penambahan dan pada kumpulan puisi cinta karya Kahlil Gibran yang berjudul "MGKSPJ" berfungsi menyatakan ada penambahan makna pada larik yang menyebabkan larik tersebut menjadi wacana yang padu. Konjungsi koordinatif penambahan dan sangat diperlukan pada setiap larik kumpulan puisi cinta karya Kahlil Gibran yang berjudul "MGKSPJ" sebagai salah satu alat untuk mendukung larik puisi tersebut menjadi wacana yang utuh, jika tidak digunakan akan menyebabkan ketidak paduan, dan akan menyulitkan pembaca untuk memahami maksud dari bait puisi tersebut. Pada kumpulan puisi cinta karya Kahlil Gibran yang berjudul " $M G K S P J$ ” konjungsi kordinatif penambahan dan tidak hanya digunakan untuk menghubungkan larik puisi yang ada dalam satu bait, melainkan juga menghungkan antara bait puisi sebelumnya ataupun sesudahnya.

Konjungsi koordinatif penambahan dan yang terdapat pada umpulan puisi cinta karya Kahlil Gibran yang berjudul "MGKSPJ" tidak hanya terletak di tengah larik puisi melainkan bisa terletak di awal larik puisi. Hal ini dapat membuktikan bahwa konjungsi koordinatif penambahan dan sangat diperlukan keberedaanya agar larik puisi tersebut menjadi wacana yang padu.

\section{Konjungsi Koordinatif Perlawanan}

Konjungsi koordinatif perlawanan tetapi sama halnya dengan konjungsi koordinatif penambahan dan yang menghubungkan larik yang setara, tapi perlu digaris bawahi bahwa di sini ada kata perlawanan. Konjungsi yang menyatakan perlawanan jika larik puisi yang mengandung konjungsi perlawanan dari proposisi yang terkandung dalam larik sebelumnya atau pun larik sesudahnya pada kumpulan puisi cinta karya Kahlil Gibran yang berjudul "MGKSPJ”.

Penggunaan konjungsi koordinatif perlawanan tetapi yang digunakan oleh penulis untuk menghubungkan antara larik puisi baik sesudah atau sebelum bait penggunaan konjungsi ini sudah tepat karena penulis ingin memberikan penjelasan melalui digunakannya beberapa konjungsi perlawanan tetapi pada larik kumpulan puisi cinta karya Kahlil Gibran yang berjudul "MGKSPJ" bahwa cinta yang dirasakan Kahlil Gibran (penulis puisi) tidak memberikan kebahagian, melainkan 
penderitaan. Berdasarkan hasil pengklasifikasian dalam satu bait puisi itu tidak hanya menggunakan satu jenis konjungsi koordinatif perlawanan tetapi, melainkan juga menggunakan konjungsi koordinatif penanmbahan dan baik di dalam larik yang sama atau pun di dalam bait puisi yang berbeda.

\section{Konjungsi Subordinatif Atribut}

Konjungsi subordinatif atributif pada kumpulan puisi cinta karya Kahlil Gibran yang berjudul “MGKSPJ”digunakan untuk menghubungkan larik puisi yang tidak setara dan satuan kesatuan larik yang mengikat sehingga bisa menjadi sebuah wacana yang padu. Sama halnya dengan konjungsi koordinatif penambahan dan konjungsi subordiantif atributif yang sangat banyak digunakan dalam larik puisi pada kumpulan puisi cinta karya Kahlil Gibran yang berjudul "MGKSPJ”, tetapi ada juga larik puisi yang menggunakan konjungsi yang lain, tidak semua larik puisi yang ada pada bait puisi ini hanya menggunakan satu jenis konjungsi saja, jika itu terjadi bisa menyebabkan larik puisi tersebut menjadi wacana yang tidak koheren.

Konjungsi subordinatif atributif yang dan karena pada kumpulan ini digunakan selain menghubungkan larik yang tidak setara juga digunakan untuk menyampaikan maksud dari penulis (Kahlil Gibran) kepada pembaca bahwa untuk mendapatkan sesuatu itu perlu diperjuangkan, terutama cinta walaupun akhirnya berakhir dengan kekecewan karena penulis (Kahlil Gibran) karena sampai akhir hayatnya tidak pernah hidup dengan seorang yang dicintai dan selalu berakhir dengan perpisahan atau kematian.

\section{Konjungsi Subordinatif Waktu}

Konjungsi subordinatif waktu yang digunakan pada larik kumpulan puisi cinta karya Kahlil Gibran yang berjudul "MGKSPJ" tidak hanya menggunakan konjungsi subordinatif waktu saja dalam satu bait puisi, melainkan menggunakan konjungsi yang lain seperti yang telah dijelaskan di atas konjungsi apa saja yang digunakan. Penggunaan kohesi gramatikal konjungsi subordinatif waktu puisi ini mendukung larik puisi ini menjadi sebuah wacana yang padu.

Hal ini sudah terbukti bahwa pada larik kumplan puisi ini tidak hanya memperhatikan jenis kohesi gramatikal referensi, substitusi, dan elipsis juga memperhatikan pemilihan jenis konjungsi yang digunakan agar larik puisi tersebut menjadi satu kesatuan wacana yang utuh guna untuk memudahkan pembaca memahami maksud dari larik puisi tersebut sesuai dengan interpretasi dari masing-masing pembaca.

Konjungsi koordinatif penambahan dan terdapat pada bait kedua dan keenam puisi yang berjudul "Gita Cinta" dan bait kelimabelas puisi yang berjudul "Bekerja dengan Cinta", konjungsi koordinatif perlawanan terdapat pada bait kelima dan kenam puisi yang berjudul "Cinta" dan bait keempat puisi yang berjudul "Bekerja dengan Cinta". Konjungsi subordnatif atributif yang terdapat pada bait ketiga puisi yang berjdul "Cinta",bait kesatu puisi yang berjudul "Panggilangan Pecinta", konjungsi subordinatif akibatan terdapat bait keenambelas" puisi yang berjudul "Bekerja dengan Cinta", dan konjungsi subordinatif waktu terdapat pada bait keenam puisi yang berjudul "Cinta". Konjungsi subordinatif waktu. Konjungsi waktu yang digunakan adalah waktu lampau dan waktu yang akan datang.

\section{SIMPULAN}

Berdasarkan hasil analisis dan pembahasan dapat disimpulkan bahwa ada tiga jenis kohesi gramatikal referensi yang digunakan pada kumpulan puisi cinta karya Kahlil Gibran yang berjudul " $M G K S P J$ ” yaitu, referensi eksofora, anafora, dan katafora. Kohesi gramatikal subtitusi nomina adalah jenis substitusi yang digunakan pada kumpulan puisi cinta karya Kahlil Gibran yang berjudul "MGKSPJ". Ada dua jenis kohesi grmatikal elipsis yang digunakan pada kumpulan puisi cinta karya Kahlil Gibran yang berjudul "MGKSPJ", yaitu elipsis nomina dan elipsis klausa, dan ada empat jenis konjungsi yang digunakan pada kumpulan puisi cinta karya Kahlil Gibran yang berjudul "MGKSPJ”, yaitu konjungsi koordinatif penambahan dan, konjungsi koordinatif perlawanan, konjungsi subordinatif atributif, dan konjungsi subordinatif waktu.

Referensi eksofora yang digunakan pada masing-masing judul puisi tersebut mengacu pada penulis puisi, yaitu Kahlil Gibran yang dapat berperan sebagai pelaku cinta dan korban cinta. Referensi anafora yang digunakan pada kumpulan puisi cinta karya Kahlil Gibran yang berjudul “Melancholic Gibran Karya- karya Syahdu Penggugah Jiwa” mengacu pada korban cinta dan sesuatu yang berkaitan dengan alat cinta, misalnya bunga mawar, musik, bibir dan lain sebagainya. Referensi katafora yang digunakan pada kumpulan puisi cinta karya Kahlil Gibran yang berjudul "Melancholic Gibran Karya- karya Syahdu Penggugah Jiwa” prononima atau kata ganti yang mengacu secara katafora dalam kumpulan bait puisi tidak hanya mengacu pada korban cinta, melainkan juga dapat mengacu pada sesuatu di luar manusia atau insani. Unsur yang diganti maupun unsur yang tergantikan pada kumpulan bait puisi berupa nomina atau kata benda dan prononima atau kata ganti, tetapi tidak mengurangi bait puisi tersubut menjadi sebuah wacana yang padu karena berfungsi menghadirkan bentuk variasi, menghindari kemonotonan akibat penyebutan unsur yang sama berkali-kali, dan untuk memperoleh unsur pembeda dalam setiap larik pada kumpulan puisi cinta karya Kahlil Gibran yang berjudul "Melancholic Gibran Karya-karya Syahdu Penggugah Jiwa. Elipsis yang digunakan pada kumpulan puisi ini untuk mendukung setiap larik menjadi wacana yang padu. Setiap bait yang ada pada bait puisi ini jarang sekali menggunakan kohesi gramatikal elipsis, karena kohesi gramatikal elipsis sebenarnya sering digunakan pada bahasa lisan karena di dalam bahasa lisan ada yang namanya komonikatif antara penutur dan mitra tutur. 
Pada kumpulan puisi cinta karya Kahlil Gibran yang berjudul "Melancholic Gibran Karya-karya Syahdu Penggugah Jiwa” didalam satu larik atau bait tidak hanya menggunakan satu jenis konjungsi, konjungsi yang digunakan lebih dari satu. Konjungsi yang digunakan pada kumpulan puisi cinta karya Kahlil Gibran yang berjudul "Melancholic Gibran Karya-karya Syahdu Penggugah Jiwa" tidak hanya digunakan untuk menghubungkan antar larik, tetapi juga digunakan untuk menghubungkan antar bait agar manjadi wacana yang baik dan padu pada baik antar larik maupun antar bait. Penelitian tentang kohesi dan koheresi memang belum banyak dilakukan khususnya kohesi dan koherensi yang digunakan pada bidang karya sastra. Ada beberapa penelitian yang meneliti tentang kohesi dan koherensi yang digunakan pada bidang karya sastra, tetapi harus selalu dikembangkan karena penelitian ini sangat minim. Penelitian tentang kohesi dan koherensi pada bidang karya sastra khusunya karya sastra puisi sudah pernah dilakukan, tetapi bukan puisi yang berbahasa Indonesia, melainkan puisi yang berbahasa Jawa. Pada penelitian ini juga bukan murni menggunakan bahasa Indonesia, melainkan bahasa terjemahan dari bahasa Ingris ke dalam bahasa Indonesia, jadi perlu dilakukan penelitian lanjutan mengenai penelitan tentang kohesi dan koherensi pada karya sastra, khususnya puisi yang murni menggunakan bahasa Indonesia.

Penelitian mengenai kohesi gramatikal dalam bidang sastra, khususnya puisi menarik untuk dilakukan penelitian lanjutan karena bahasa puisi itu memiliki ciri bahasa yang khas tergantung dari bahasa masing-masing penulis karena bahasa yang menarik itulah perlu dilakukan penelitian lanjutan. Penelitian lanjutan perlu dilakukan sebagai bahan perbandingan hasil penelitian ini dengan penelitian selanjutnya.

\section{DAFTAR RUJUKAN}

Aflahah. (2012). Kohesi dan Koherensi dalam Wacana. Okara: Jurnal Bahasa dan Sastra, 6(1), 1-18.

Alfaris, R. (2015). Analisis Kohesi Gramatikal dan Leksikal dalam Novel Wulandari Karya Yunani. Jurnal Program Studi Pendidikan Bahasa dan Sastra Jawa, 6(4), 76-83.

Anjani, E. S. (2013). Kohesi dan Koherensi Wacana Stand Up Comedy Prancis dan Indonesia. Kawistara: The Journal of Social Sciences and Humanities, 3(33), 227-334.

Ardila, R. (2018). Gaya Kepemimpinan dalam Novel Sang Guru Karya Kahlil Gibran. 6(1), 42-50. https://doi.org/10.31102/wacanadidaktika.6.01.41-50

Arifin, B. (2012). Alat Kohesi Wacana Bahasa Indonesia. Malang: Gunung Samudera.

Baryadi, I. P. (2002). Dasar-dasr Analisis Wacana dalam Ilmu Bahasa. Jogjakarta: Pustaka Gondho Suli.

Bunga, R. D. (2017). Kekohesifan Dalam Antologi Cerpen Wajah Indoenesiaku Karya Siswa SMA Flores Lembata. 2(1), 176186.

Fais, F. (2005). Gibranisme: Antara Eksistensialisme dan Romantisme. 15(2), 183-201.

Halliday, M. A. K., \& Hasan, R. (1976). Cohesion in English. London: Longman Group Ltd.

Herianah. (2014). Kohesi Gramatikal dan Leksikal dalam Wacana Puisi “Tadarusku Untukmu” Karya Sus S. Hardjono. Metalingua, 12(1), 57-69.

Izar, J., Afria, R., \& Sanjaya, D. (2019). Analisis Aspek Gramatikal dan Leksikal pada Cerpen Ketek Ijo Karya M. Fajar Kusuma. Titian: Jurnal Ilmu Humaniora, 3(1), 55-72.

Indrawati, W. D. (2015). Analisis Kohesi dan Koherensi dalam Novel Krikil-Krikil Pasisir karya Tamsir As. ADITYA Pendidikan Bahasa dan Sastra Jawa, 7(4), 20-25.

Mandia, I. N. (2015). Analisis Wacana Karya Tulis Praskripsi Mahasiswa Jurusan Akuntansi Politeknik Negeri Bali. Soshum: Jurnal Sosial dan Humaniora, 5(3), 205-216.

Mandowen, K. Y. (2016). Kohesi Gramatikal "Referensi” dalam Wacana Mop Melayu Papua Pada Rubrik Breakboss Surat Kabar Harian Cenderawasih Pos. MELANESIA: Jurnal Ilmiah Kajian Sastra dan Bahasa, 1(1), 51-75.

Muhyidin, A. (2018). Kohesi Gramatikal Konjungsi dalam Karya Sastra dan Implikasinya bagi Pembelajaran Bahasa Indonesia di SMA. Lensa: Kajian Kebahasaan, Kesusastraan, dan Budaya, 8(2), 161-175. https://doi.org/10.26714/lensa.8.2.2018.161-175

Mulyana. (2005). Kajian Wacana: Teori, Metode\& Aplikasi Prnsip-prinsip Analisis Wacana. Jogjakarta: Tiara Wacana.

Rani, Bustanul, A., \& Martutik. (2004). Analisis Wacana: Sebuah Kajian. Malang: Bayu Media.

Sari, S. M. (2017). Kohesi Gramatikal dan Leksikal dalam Genre Narasi "Batu Belah". Paidagogeo, 2(3), $140-147$.

Sayuti, A. S. (2002). Berkenalan dengan Puisi. Yogyakarta: Gama Media.

Sudaryanto. (1988). Metode Linguistik Bagian Pertama Ke Arah Memahami Metode Lingustik. Yogyakarta: Gadja Mada University Pers.

Sugiarti. (2002). Pengantar dan Kajian Proasa Fiksi. Malang.

Sumarlam. (2003). Teori dan Praktik Analisis Wacana. Surakarta: Pustaka Cakra.

Teeuw, A. (2015). Sastra dan Ilmu Sastra. Bandung: Pustaka Jaya.

Waluyo, H. J. (1987). Teori dan Apresiasi Puisi. Jakarta: Erlangga.

Wiana, D. (2011). Analisis Kohesi pada Rubik "Opini” Surat Kabar Analisa. 4(2), 652-666.

Widayati, S. (2017). Analisis Wacana Cerpen “Tinggal Matanya Berkedip-kedip” Karya Ahmad Tinjauan Aspek Sosial Budaya serta Penanda Kohesi Gramatikal dan Leksikal. Edukasi Lingua Sastra, 15(1), 74-88. 
Wiyanti, E. (2016). Kajian Kohesi Gramatikal Substitusi dan Elipsis Dalam Novel "Laskar Pelangi” Karya Andrea Hirata. Jurnal Pendidikan Bahasa dan Sastra, 16(2), 188-202.

Wiyanti, E., \& Dini, H. (2017). Analisis Kohesi Anafora dan Katafora pada Tajuk Rencana Koran Kompas. BAHASTRA, 37(1), 9-23.

Yolanda, E., Zahar, E., \& Sujoko. (2018). Fungsi Substitusi sebagai Bentuk Penghilangan Kemonotonan Dalam Novel Surga Yang Tak Dirindukan 2 Karya Asma Nadia. Aksara: Jurnal Ilmiah Pendidikan Bahasa dan Sastra Indonesia, 2(2), 21-28.

Yuniati, I., \& Chairunnisa. (2018). Kohesi pada Novel Cinta Suci Zahrana Karya Habiburahman El Shirazy. Jurnal Kajian Bahasa, Sastra dan Pengajaran, 1(2), 182-201.

Zulaiha, W. P. (2014). Analisis Kohesi Gramatikal dan Leksikal dalam Novel Jemini Karya Suparto Brata. ADITYA Pendidikan Bahasa dan Sastra Jawa, 5(1), 56-62. 